1 Department of Biorregulation, Health \& Science Institute, Federal University of Bahia (UFBA), Salvador, BA, Brazil ${ }^{2}$ State University of Feira de Santana (UEFS), Feira de Santana, BA, Brazil

${ }^{3}$ Department of Endocrinology, Royal Devon \& Exeter Hospital, Exeter, United Kingdom

${ }^{4}$ Department of Endocrinology, Universitair Ziekenhuis

Brussel, Vrije Universiteit Brussel (VUB), Brussels, Belgium

${ }^{5}$ Division of Endocrinology and Metabolism, Department of Medicine, Federal University of Paraná (UFPR), Curitiba, PR, Brazil ${ }^{6}$ Thyroid Sections, Durand Hospital, Buenos Aires, Argentina
Correspondence to: Helton Estrela Ramos Department of Biorregulation, Federal University of Bahia Av. Reitor Miguel Calmon, s/n Vale do Canela, sala 300 40110-902 - Salvador, BA, Brazil ramoshelton@gmail.com

Received on Mar/27/2014 Accepted on May/4/2014 DOI: 10.1590/0004-2730000003382

\section{An international survey of screening and management of hypothyroidism during pregnancy in Latin America}

\author{
Uma avaliação internacional do rastreio e manejo do \\ hipotireoidismo durante a gestação na América Latina
}

Mateus Fernandes da Silva Medeiros ${ }^{1}$, Taise Lima de Oliveira Cerqueira', Joaquim Custódio Silva Junior', Magali Teresopolis Reis Amaral'², Bijay Vaidya ${ }^{3}$, Kris Gustave Poppe ${ }^{4}$, Gisah Amaral de Carvalho ${ }^{5}$, Silvia Gutierrez', Graciela Alcaraz', Marcos Abalovich ${ }^{6}$, Helton Estrela Ramos', for the Latin American Thyroid Society

\begin{abstract}
Objective: To determine how endocrinologists in Latin America deal with clinical case scenarios related to hypothyroidism and pregnancy. Materials and methods: In January 2013, we sent an electronic questionnaire on current practice relating to management of hypothyroidism in pregnancy to 856 members of the Latin AmericanThyroid Society (LATS) who manage pregnant patients with thyroid disease. Subsequently, we have analyzed responses from physician members. Results: Two hundred and ninety-three responders represent clinicians from 13 countries. All were directly involved in the management of maternal hypothyroidism and $90.7 \%$ were endocrinologists. The recommendation of a starting dose of L-thyoxine for a woman diagnosed with overt hypothyroidism in pregnancy, preconception management of euthyroid women with known thyroid autoimmunity and approach related to ovarian hyperstimulation in women with thyroid peroxidase antibodies were widely variable. For women with known hypothyroidism, $34.6 \%$ of responders would increase L-thyroxine dose by $30-50 \%$ as soon as pregnancy is confirmed. With regard to screening, $42.7 \%$ of responders perform universal evaluation and $70 \%$ recommend TSH $<2.5 \mathrm{mUI} / \mathrm{L}$ in the first trimester and TSH $<3 \mathrm{mUI} / \mathrm{L}$ in the second and third trimester as target results in known hypothyroid pregnant women. Conclusion: Deficiencies in diagnosis and management of hypothyroidism during pregnancy were observed in our survey, highlighting the need for improvement of specialist education and quality of care offered to patients with thyroid disease during pregnancy in Latin America. Arq Bras Endocrinol Metab. 2014;58(9):906-11
\end{abstract}

\section{Keywords}

Hypothyroidism; thyroid; pregnancy

\section{RESUMO}

Objetivo: Determinar, na América Latina, como os endocrinologistas lidam com cenários clínicos relacionados ao hipotireoidismo durante a gravidez. Materiais e métodos: Em Janeiro de 2013, foi enviado, para 856 membros da Sociedade Latino-Americana de Tireoide (LATS), um questionário eletrônico sobre práticas relacionadas ao manejo do hipotireoidismo durante a gestação. Subsequentemente, as respostas foram analisadas. Resultadlos: Duzentos e noventa e três médicos, de 13 países, responderam ao questionário. Todos estavam diretamente envolvidos no manejo de hipotireoidismo materno e $90,7 \%$ eram endocrinologistas. As recomendações de iniciar terapia com levotiroxina para uma mulher com hipotireoidismo franco durante a gravidez e o manejo na fase de pré-concepção de pacientes eutireoidianas com conhecida autoimunidade em hiperestimulação ovariana variaram amplamente. Para mulheres com hipotireoidismo conhecido, apenas $34,6 \%$ dos respondedores aumentariam a dose de levotiroxina em 30-50\% assim que a gravidez fosse confirmada. Em relação ao rastreamento, $42,7 \%$ dos respondedores realizam avaliação universal. Setenta por cento recomendam TSH $<2,5 \mathrm{mUI} / \mathrm{L}$ no primeiro trimestre e $\mathrm{TSH}<3 \mathrm{mUI} / \mathrm{L}$ no terceiro trimestre como alvos. Conclusão: Observamos problemas no diagnóstico e manejo do hipotireoidismo durante a gestação, enfatizando a necessidade, na América Latina, de melhoria na educação médica continuada em áreas como tireoiodopatias na gestação. Arq Bras Endocrinol Metab. 2014;58(9):906-11

Descritores

Hipotireoidismo; tireoide; gestação 


\section{INTRODUCTION}

$\mathrm{H}$ ypothyroidism complicates $2-3 \%$ of pregnancies, and up to $6,3 \%$ if the trimester-specific reference range is used (1). Over the past few years there has been a major expansion of our knowledge regarding thyroid disorders during pregnancy and its multiple adverse consequences, affecting pregnant women and their unborn children. The hypothyroid pregnant women have increased rates of miscarriage, preeclampsia, placental abruption, growth restriction, prematurity, stillbirths and their fetuses are at risk for impaired neurologic development $(2,3)$. Although it is well known that overt hypothyroidism $(\mathrm{OH})$ have deleterious impact on obstetrical outcomes, crucial data regarding treatment of subclinical hypothyroidism $(\mathrm{SCH})$, euthyroid women positive for thyroperoxidase (TPO) and/or thyroglobulin ( $\mathrm{Tg}$ ) antibody (TAb+) and isolated maternal hypothyroxinemia is critically needed $(4,5)$.

In 2010 , significant variability in diagnostic and therapeutic management have been reported by a questionnaire which assessed management of hypothyroidism during pregnancy in Europe (6). However, even with novel prospective studies, many controversies still exist regarding the most appropriate approach for the $\mathrm{L}_{-} \mathrm{T}_{4}$ dose adjustment in pregnancy $(7,8)$. This study aims to analyze the management approach for hypothyroidism during pregnancy in Latin America and compare with data from Europe.

\section{MATERIALS AND METHODS}

The original questionnaire validated in the European survey was translated to Portuguese and Spanish by the authors (Appendix 1) (6). It was sent through e-mail to members of the Latin American Thyroid Society (LATS) who had their electronic addresses available (www.lats.org). In January 2013, 856 physicians living in Latin America with e-mail address available on LATS website were found. Four repeated messages were sent to these LATS members, in intervals of a couple of weeks. From the original 856 members of LATS, 180 $(21 \%)$ did not receive the questionnaire by e-mail because their electronic addresses were incorrect. Results are given as frequencies, and chi-squared test was used to compare responses. A p-value $<0.05$ was considered significant.

\section{RESULTS}

\section{Characteristics of responders}

Three hundred eleven responses were received. Nine were excluded because the responders were not involved with pregnancy care. The remaining 293 participants were retained for analyses and corresponded to $90 \%$ of endocrinologists; $0.3 \%$ nuclear medicine specialists; $4.2 \%$ surgeons; $2 \%$ of family practitioners; and $3.5 \%$ of others specialities, from thirteen countries. Most responses were from Brazil (31.7\%), but there were also responders from, Mexico (25.0), Argentina (23.1\%), Colombia (12.5\%), Peru (2.2\%), Chile (1.6\%), Bolivia (1.0\%), Uruguay and El Salvador (0.6\%, both); other four countries (French Guyana, Paraguay, Venezuela, Guatemala) had one response each (1.2\%).

\section{Diagnosis and treatment of overt hypothyroidism during pregnancy}

For a hypothyroid woman planning pregnancy (Case 1, Table 1), a majority of responders (53\%) preferred increasing the $\mathrm{L}_{-} \mathrm{T}_{4}$ dose only after performing biochemical tests while $34.6 \%$ have stated that this dose increase should be done immediately after pregnancy is suspected (Table 1). Indeed, in this setting, 6.7\% recommended to increase the dose by two additional tablets weekly as soon as pregnancy is confirmed and $5.7 \%$ would increase the dose in the preconception period (Table 1). In Latin America, for women at preconception (Case 1, Table 1), $\mathrm{L}-\mathrm{T}_{4}$ adjustment have presented a trend of less recommendation than in Europe (34.6\% vs. 44.4\%, $\mathrm{p}<0.5)$, and the responders presented a not significant more indication of thyroid function tests only after

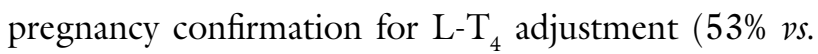
$43.2 \%, \mathrm{p}<0.5$ ) if with we compare Europe and Latin America, respectively (Table 1).

For a woman with autoimmune hypothyroidism undergoing an assisted reproduction technology (Case 2, Table 1), a majority of responders $(68 \%)$ preferred to adjust the $\mathrm{L}^{-} \mathrm{T}_{4}$ dose following thyroid function tests immediately after the ovarian hyperstimulation, and this was higher but did not reach statistical significance when compared with previous results in Europe (57.1\%, $\mathrm{p}=0.07)$. Conversely, in Latin America, significantly less responders (1.8\%) recommended to increase the $\mathrm{L}_{-} \mathrm{T}_{4}$ just before the ovarian hyperstimulation or in-vitro fertilization (vs. $24.2 \%$ in the European survey, $\mathrm{p}<0.05$ ) (Table 1 ). 
Table 1. Cases scenarios and comparison of hypothyroidism during pregnancy management in Europe and Latin America

\begin{tabular}{|c|c|c|}
\hline \multirow{2}{*}{$\begin{array}{l}\text { Case 1. A } 26 \text { year old woman has autoimmune hypothyroidism and is euthyroid (prepregnancy TSH } 2.4 \mathrm{mUI} / \mathrm{L} \text { ) on } \\
\text { L-thyroxine replacement. She expresses her wish to become pregnant soon. What advice would you give? }\end{array}$} & \multicolumn{2}{|c|}{ Responders, $\mathbf{n}(\%)$} \\
\hline & ETA & LATS \\
\hline Increase the dose of L-thyroxine by $30-50 \%$ as soon as pregnancy is confirmed & $72(44.4)$ & $98(34.6)^{*}$ \\
\hline Increase the dose of L-thyroxine by two tablets per week as soon as pregnancy is confirmed & $9(5.6)$ & $19(6.7)$ \\
\hline Check thyroid function tests as soon as pregnancy isconfirmed and increase the dose of L-thyroxine if necessary & $70(43.2)$ & $150(53.0)^{\dagger}$ \\
\hline Increase L-thyroxine dose before pregnancy & $11(6.8)$ & $16(5.7)$ \\
\hline \multicolumn{3}{|l|}{$\begin{array}{l}\text { Case 2. A } 26 \text { year old woman has autoimmune hypothyroidism and is euthyroid (TSH } 1.8 \mathrm{mUI} / \mathrm{L} \text { ) on L-thyroxine } \\
\text { replacement. She is infertile and should undergo an ovarian hyperstimulation before an IVF procedure. What advice } \\
\text { would you give? }\end{array}$} \\
\hline Increase the dose of L-thyroxine by $30-50 \%$ as soon as pregnancy is confirmed & $30(18.6)$ & $40(14,1)$ \\
\hline Immediately increase the dose of L-thyroxine before the hyperstimulation, to obtain a low normal TSH level & - & $45(15,9)$ \\
\hline Check thyroid function tests after hyperstimulation and increase the dose of L-thyroxine if necessary & $92(57.1)$ & $193(68,2)^{\S}$ \\
\hline \multicolumn{3}{|l|}{$\begin{array}{l}\text { Case 3. A } 24 \text { year old woman is } 12 \text { weeks pregnant and just been diagnosed with overt primary hypothyroidism } \\
\text { (TSH } 86 \text { mUl/I). What dose of L-thyroxine would you initially start? Would you advise the above patient, who has } \\
\text { been diagnosed with overt hypothyroidism in the late first trimester, to consider abortion? What tests would you use } \\
\text { to monitor the dose of L-thyroxine during pregnancy? What are the target thyroid test results you aim to achieve } \\
\text { with L-thyroxine replacement in pregnancy? }\end{array}$} \\
\hline Start on a small dose (e.g. $25-50$ mcg daily) & $10(6.2)$ & $25(8.8)$ \\
\hline Start on a full dose (e.g. 100-125 mcg daily) & $74(45.7)$ & $116(41.0)$ \\
\hline Start on a dose based on pregnancy-adapted body weight & $29(17.9)$ & $71(25.1)$ \\
\hline Start for a few days on a double dose (e.g. $200 \mathrm{mcg}$ daily), then a dose based on pregnancy-adapted body-weight & $40(24.7)$ & $54(19.1)$ \\
\hline Start on a dose based on pre-treatment TSH level & $5(3.1)$ & $6(2.1)$ \\
\hline Other & $2(1.2)$ & $11(3.9)^{*}$ \\
\hline
\end{tabular}

* Include: start on a small dose and progression to a full dose in 7 days $(n=6)$; start on a high full dose based $(2.3 \mathrm{mcg} / \mathrm{kg})$ on pregnancy body weight $(n=5)$.

${ }^{\dagger} p<0,5 .{ }^{8} p=0,07$.

In the setting of overt hypothyroidism $(\mathrm{OH})$ diagnosed during first trimester (Case 3, Table 1), suggestions for starting regimes to initiate $\mathrm{L}-\mathrm{T}_{4}$ were widely variable (Table 1 ). Most responders judged full $\mathrm{L}_{-} \mathrm{T}_{4}$ dose replacement necessary, either empirically $(41 \%)$ or based on body weight (25.1\%); conversely, $8.8 \%$ of responders felt that a high dose was unnecessary and preferred small starting dose $(25 \mathrm{mcg} /$ daily) (Table 1$)$. There were no significant differences between LATS and ETA members responses, when choosing a starting low dose of L-thyroxine $(8,8 \%$ vs. $6.2 \%)$, or starting the full dose ( $41 \%$ vs. $45.7 \%, \mathrm{p}=0.5$ ) (Table 1$)(6)$.

Seven different combinations of thyroid function tests were chosen to monitor the treatment but TSH associated with $\mathrm{FT}_{4}$ was preferred by $54.3 \%$ of the physicians. The majority of responders $(70 \%)$ have recommended to keep the TSH $<2.5 \mathrm{mUI} / \mathrm{L}$ in the first trimester and $<3 \mathrm{mUI} / \mathrm{L}$ in the second and third trimester; this was significantly higher compared with the last European survey $(56.6 \%), \mathrm{p}<0.05$. Only $7.3 \%$ of responders targeted to keep thyroid function tests within laboratory reference range ( $v s .8 .1 \%$ in Europe, $\mathrm{p}=$ 0.6) (6). Maternal $\mathrm{OH}$ during the first trimester have induced almost all the participants $(96 \%)$ not to consider abortion in such a situation, but $4 \%$ would discuss or recommend abortion. In contrary, in Europe, 18\% would recommend abortion or, at least, discuss this option $(7 \%), \mathrm{p}<0.05$.

\section{Screening hypothyroidism in pregnancy}

In Latin America, $38.4 \%$ (vs. $43 \%$ in Europe) of responders use universal screening strategy and $43 \%$ prefer a case-finding approach in high-risk groups. Surprisingly, 19.4\% (vs. 17\% in Europe) still reported absence of any screening strategy in their centers. The timing of screening was variable: $62.5 \%$ (vs. $67 \%$ in Europe) reported screening before conception, $24.5 \%$ (vs. $22 \%$ in Europe) at the time of the first prenatal visit and $10 \%$ (vs. 11\% in Europe) had no strategy for this issue. Tests chosen for screening were highly variable and did not reached statistic difference if compared with $\mathrm{Eu}$ rope: TSH with TPO-Ab (47.5\%); TSH alone (38.8\%); TSH with $\mathrm{FT}_{4}$ or $\mathrm{TT}_{4}(33.7 \%) ; \mathrm{FT}_{4}(35 \%) ; \mathrm{FT}_{3}$ or $\mathrm{TT}_{3}(9.4 \%) ; \mathrm{TT}_{4}(6.8 \%)$. When asked about retesting (double screening) in women whose initial screening was normal, $43.9 \%$ (vs. $53 \%$ in Europe; $\mathrm{p}=0,2$ ) would 
recommend this in the presence of thyroid antibodies while $30 \%$ ( vs. $31 \%$ in Europe) would not repeat.

Once screening has been performed, physicians have fundamentally addressed the decision of $\mathrm{L}_{-} \mathrm{T}_{4}$ treatment based on different criteria: TSH above 2.5 $\mathrm{mIU} / \mathrm{L}, 50.8 \%$; TSH above the trimester-specific reference range, $37.7 \%$; TSH above $5 \mathrm{mIU} / \mathrm{L}, 20 \%$; TSH above the population reference range, $11.2 \%$; $\mathrm{FT}_{4}$ bellow the trimester-specific reference range, $22.7 \%$; and other criteria, $5 \%$. There was inconsistency in responders' definition and management of maternal isolated hypothyroxinemia, with $59.5 \%$ (vs. $48 \%$ in Europe; $\mathrm{p}$ $=0,1)$ of physicians choosing follow-up without treatment and $36.8 \%$ (vs. 38\% in Europe) recommending $\mathrm{T}_{4}$ replacement.

The management was different in women with TSH level $>2.5 \mathrm{mUI} / \mathrm{L}$ (but $<5 \mathrm{mUI} / \mathrm{L}$ ) with positive or negative thyroid antibodies when comparing answers from Latin America and Europe (Figure 1). Once TSH levels are between 2.5 to $5 \mathrm{mUI} / \mathrm{L}$ and TPO-Ab are detected, physicians have the following decision: treatment with $\mathrm{L}-\mathrm{T}_{4}(14.5 \%$ vs. $10 \%$ in Europe); close follow-up without treatment $(81.4 \%$ vs. $73 \%$ in Europe; $\mathrm{p}$ $=0,06)$; no follow-up and/or treatment $(4.1 \%$ vs. $17 \%$ in Europe; $p=0,4)$ (Figure 1). We could not find any significant difference for all management aspects between responders from countries in Latin America.

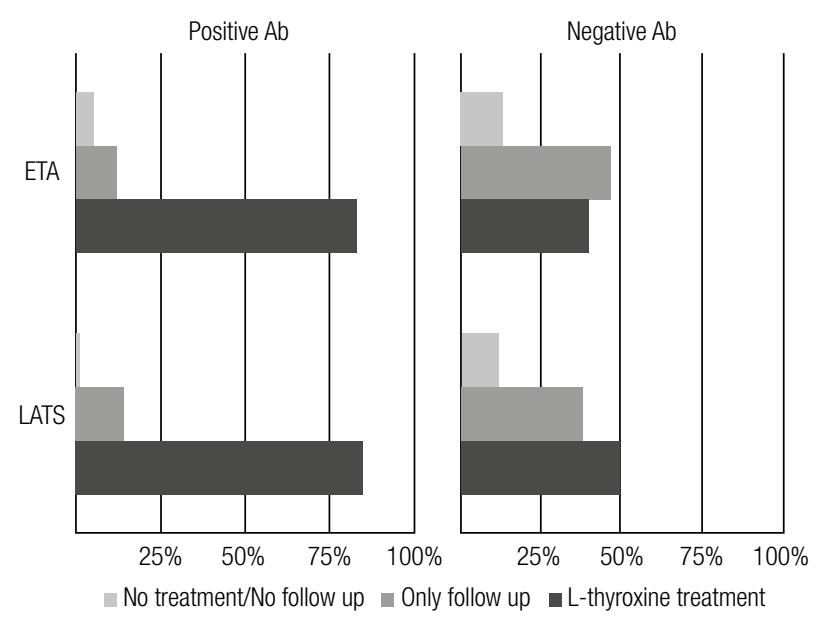

Figure 1. Management in pregnant women with TSH level $>2.5 \mathrm{mUl} / \mathrm{L}$ (but $<5 \mathrm{mUl} / \mathrm{L}$ ) with positive or negative thyroid antibodies.

\section{DISCUSSION}

With regard to maternal $\mathrm{OH}$ diagnosed during pregnancy, the current guidelines provide recommendations to start treatment and normalize thyroid function as rapidly as possible $(5,9)$. The Endocrine Society published in 2012 that when serum TSH is first checked during pregnancy, the average increments of $\mathrm{L}_{4} \mathrm{~T}_{4}$ needed are $75-100 \mathrm{mcg} / \mathrm{d}$ for those with a serum TSH above $20 \mathrm{mUI} / \mathrm{L}$ (5). In our study, practices regarding the $\mathrm{L}_{-} \mathrm{T}_{4}$ starting dose were very variable, with only $41 \%$ reported starting full doses for this case. The publication of the Endocrine Society guidelines seems have not created a change in the clinical variability of decisions of LATS regarding maternal $\mathrm{OH}$ treatment once the responses are comparable with the Europe $(5,6)$. Indeed, the vast majority of hypothyroid women are not managed by endocrinologists during pregnancy, and the published subspecialty guidelines related to thyroid in pregnancy might not reach the relevant audience and be ignored. The goal of $\mathrm{L}_{-} \mathrm{T}_{4}$ treatment was to normalize maternal serum TSH values within the trimester-specific reference range for $16 \%$ of the responders and to a less than $2.5 \mathrm{mUI} / \mathrm{L}$ (first trimester) and $3.0 \mathrm{mUI} / \mathrm{L}$ (second and third trimester) in $70 \%$ of the participants (vs. $56.6 \%$ in Europe, $\mathrm{p}<0.05$ ). Perhaps the better management compared with the European answers are effect of the recent guidelines which have emphasized that a women with prior hypothyroidism should start their pregnancy with a serum TSH not higher than $2.5 \mathrm{mUI} / \mathrm{L}(5)$.

The guidelines of American Thyroid association states that treated hypothyroid patients who are newly pregnant should independently increase their dose of $\mathrm{L}-\mathrm{T}_{4}$ by $25-30 \%$ upon a missed menstrual cycle or positive home pregnancy test and notify their caregiver promptly (6). In contrary, in Latin America, only 6.7\% (vs. 5.6\% in Europe) of responders would recommend immediate adjustment in the treatment. The majority (53\%) still prefers to perform thyroid function tests first and then make $\mathrm{L}_{-} \mathrm{T}_{4}$ dose alterations. It is well known that the first prenatal visit in most centers typically does not occur until at least 8 weeks of gestation, and that the $\mathrm{L}-\mathrm{T}_{4}$ adjustments might not being addressed in a timely fashion for most patients. Even in an academic center, analyzing a cohort of 397 pregnant women followed since the first trimester with known hypothyroidism, TSH levels remained above the recommendations in $43 \%$ and $33 \%$, during the first and second trimester, respectively (6). Data may reflect that management of pregnant women with both pre-existing as well as newly diagnosed hypothyroidism are suboptimal across Latin America, however it is not clear whether this is due lack knowledge or logistical problems. 
Table 2. Utilized screening questions: pregnant with hypothyroidism

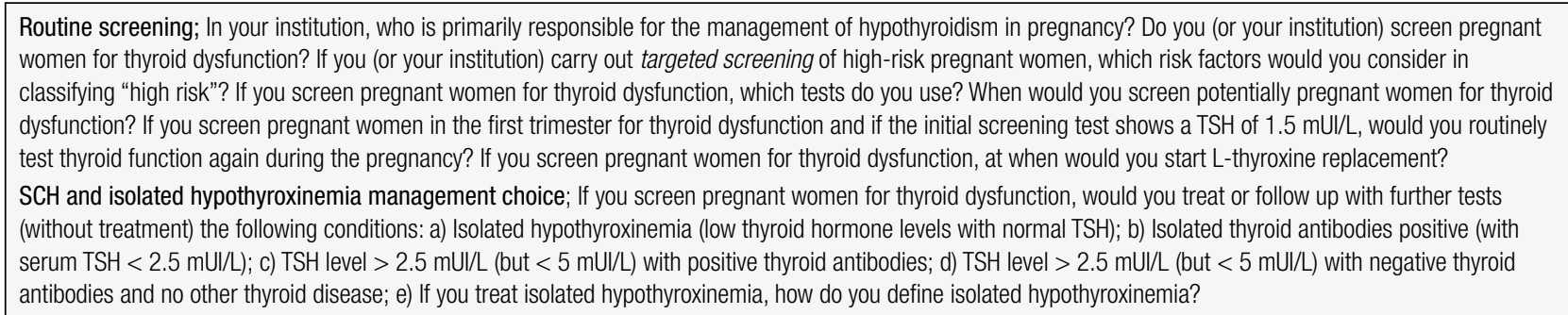

In Latin America, counseling about the necessity for $\mathrm{L}_{-} \mathrm{T}_{4}$ administration in TAb+ euthyroid women undergoing assisted reproductive procedures is more likely to be performed by obstetricians rather than endocrinologists. In infertile women, the prevalence of positivity for TPO-Ab is higher than fertile control and the pregnancy rate of those undergoing assisted reproduction is lower. In literature, there is not strong evidence to recommend $\mathrm{L}_{-} \mathrm{T}_{4}$ therapy in $\mathrm{TAb}+$ euthyroid women during assisted reproduction technology procedures (9). Negro and cols. have shown that ${\mathrm{L}-\mathrm{T}_{4}}_{4}$ treatment does not improve the delivery rate, suggesting that the autoimmunity rather than possible mild thyroid failure might be the etiology of the higher miscarriage rate. In Latin America, we have observed lower tendency to prescribe $\mathrm{L}-\mathrm{T}_{4}$ treatment prior ovarian hyperestimulation $(16 \%$ vs. $24 \%, \mathrm{p}<0.05)$ than in Europe, but $68 \%$ of responders still recommended $\mathrm{L}_{-} \mathrm{T}_{4}$ post-procedure (vs. $57.1 \%, \mathrm{P}=0.07$ ).

Thyroid dysfunction routine screening of asymptomatic pregnant women has been controversial and universal screening seems not to be associated with improved obstetric outcomes. In Latin America, $42.7 \%$ of responders recommended universal TSH screening at the first trimester visit, while $38.4 \%$ performed targeted screening of women who are at risk for thyroid dysfunction. Interestingly, almost $18.8 \%$ of the responders affirmed not to perform any type of screening in their centers and this data is similar to obtained answers from European countries (17\%) (6). The Endocrine Society guidelines could not reach agreement with regard to screening recommendations and both universal screening at ninth week of gestation or only in identified high risk patients were supported (5).

A key point is that the Endocrine Society guidelines has recommended $\mathrm{L}_{-} \mathrm{T}_{4}$ replacement in women with $\mathrm{SCH}$, mainly to avoid obstetrical outcomes (5). Assume an example of thyroid function testing in a high-risk population, in Latin America, the majority of responders used widely different criteria for indication of $\mathrm{L}_{-} \mathrm{T}_{4}$, based on different TSH cut-off or FT4 levels. From a clinical perspective, these answers illustrate the difficulties inherent in any screening process followed by management decisions.

We conclude that the management of thyroid dysfunction during pregnancy could be more uniform and standardized among clinicians from LATS and presented quite different opinions from those of the European survey. In order to reach optimal impact in the medical community, the guidelines related to the care of thyroid disorders in pregnancy could be written both by and for endocrinologists, obstetricians, internists and family practitioners.

Funding: this work was supported by grants from Fapesb (Fundação de Apoio à Pesquisa do Estado da Bahia) Grants RED010/2013, PET0002/2013. Mateus Fernandes da Silva Medeiros is supported by Grant from PROPCI/UFBA 01-2013 - PIBIC - Pró-Reitoria de Pesquisa, Criação e Inovação Prog. Institucional de Bolsas de Iniciação Científica.

Acknowledgements: we are grateful to Dr. Hans Graf for your support and contribution to LATS Pregnancy Task Force.

Disclosure: no potential conflict of interest relevant to this article was reported.

\section{REFERENCES}

1. Vaidya B, Anthony S, Bilous M, Shields B, Drury J, Hutchison S, et al. Detection of thyroid dysfunction in early pregnancy: universal screening or targeted high-risk case finding? J Clin Endocrinol Metab. 2007;92:203-7.

2. Allan WC, Haddow JE, Palomaki GE, Williams JR, Mitchell ML, Hermos RJ, et al. Maternal thyroid deficiency and pregnancy complications: implications for population screening. J Med Screen. 2000;7:127-30.

3. Stagnaro-Green A, Pearce E. Thyroid disorders in pregnancy. Nat Rev Endocrinol. 2012;8:650-8.

4. Abalovich M, Amino N, Barbour LA, Cobin RH, De Groot LJ, Glinoer $D$, et al. Management of thyroid dysfunction during pregnancy and postpartum: an Endocrine Society Clinical Practice Guideline. J Clin Endocrinol Metab. 2007;92:S1-47. 
5. De Groot L, Abalovich M, Alexander EK, Amino N, Barbour L, Cobin $\mathrm{RH}$, et al. Management of thyroid dysfunction during pregnancy and postpartum: an Endocrine Society clinical practice guideline. J Clin Endocrinol Metab. 2012;97:2543-65

6. Vaidya B, Hubalewska-Dydejczyk A, Laurberg P, Negro R, Vermiglio $F$, Poppe $K$. Treatment and screening of hypothyroidism in pregnancy: results of a European survey. Eur $\mathrm{J}$ Endocrinol. 2012;166:49-54.
7. Haymart MR. The role of clinical guidelines in patient care: thyroid hormone replacement in women of reproductive age. Thyroid. 2010;20:301-7.

8. Rinaldi MD, Stagnaro-Green AS. Thyroid disease and pregnancy: degrees of knowledge. Thyroid. 2007;17:747-53.

9. Stagnaro-Green A, Abalovich M, Alexander E, Azizi F, Mestman J, Negro R, et al. Guidelines of the American Thyroid Association for the diagnosis and management of thyroid disease during pregnancy and postpartum. Thyroid. 2011;21:1081-25. 